\title{
Feasible industrial location in Latvia: empirical analysis performance for the multinational enterprises
}

\author{
Tatjana Staube \\ Riga Technical University, Kalnciema Str. 6-210, Riga, LV 1048, Latvia
}

\begin{abstract}
The research is drawn on the main hypothesis that Latvia does not use its advantageous location effectively supported by the previous research results published in the book "Climate change and adaptation to it: Latvia". The author found the modern industrial real property market stock would not need any further growth and pointed on the local industrial real estate market misbalance. Subject of the research is the leading industrial multinational enterprises from the Baltic Sea Region working in Latvia. A focus of the research is on finding out the key principles in those companies' choice on the most appropriate territory to the industrial real estate needs and specifics of the industrial location. The survey was conducted in Latvia last year. The Paper contains the questionnaire with the projected results, the analysis of other scientists' work results on the industrial location research and the model introduced. The developed model is devoted to forecast stock of the modern industrial premises in Europe in the territory of the Republic of Latvia by the original approach of including the European climate change issue as a basis to assign the sustainable supply of the industrial premises, applying complex of the methods like logical approach and comparison, the system and dynamic row's analyses. The author expects that a climate change issue so far is not strictly regulated in Latvia and industrial business units do not measure it as the alternative or threat to further expansion. Here, the introduced algorithm model of the forecasting a supply of the spatial economic objects would show a new way of planning the industrial business scales analyzing the existing European practices and capacities. The Paper is a message to professional critical view and assessment on the model, the questionnaire and the preliminary results.
\end{abstract}

Keywords: climate change; feasible location; industry location; survey; locational strategy; market attractiveness assessment; multinational enterprises.

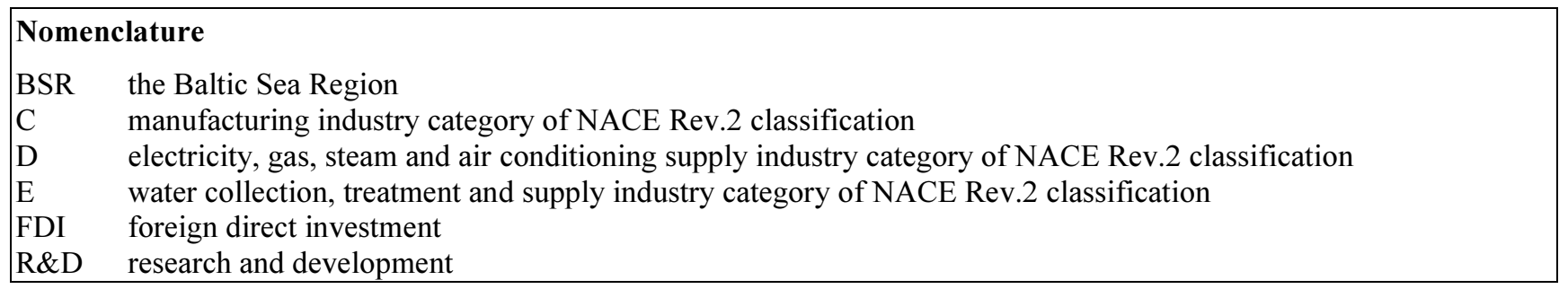

\section{Introduction}

Together with Lithuania and Estonia, Latvia creates a corridor of the economic impact between the Central European countries, Scandinavia, and Russia. Due to globalization, geographically this is a strategic place for the enterprises to allocate subsidiaries and develop the economically supportive services [1]. The accepted reason for the companies' decision in favour of new market attractiveness to allocate the subsidiary business is the costs' cutting. The academicians stand at several problems of analysing and assessing the consequences of the headquarters' decisions to enter the foreign markets. Climate change phenomenon might be one of those identifying a need of creation of the models forecasting a stock of the modern industrial real estate property offer in the real estate market [1]. The Latvian scientists theorize and pose several climate change factors of influence on the Latvian territory [2]. Increase of a number of dryness periods in summer and high temperatures in winter are accepted to be determinant [1]. According to the previous research session's results obtained from calculations on the developed algorithm model of the forecasting a supply of the spatial economic objects [3]-[8],

Corresponding author: Tatjana Staube. E-mail address: tatjana.staube@rtu.lv

http://dx.doi.org/10.3846/enviro.2014.133

(C) 2014 The Author. Published by VGTU Press. This is an open-access article distributed under the terms of the Creative Commons Attribution License, which permits unrestricted use, distribution, and reproduction in any medium, provided the original author and source are credited. 
discussed in the $2^{\text {nd }}$ World Sustainability Forum, the 25th European Conference on Operational Research, the European Real Estate Society 20th Annual Conference and the 1st Congress of World Engineers and Riga Polytechnical Institute, the author put forward a hypothesis: Latvia does not use its advantageous location effectively. For Latvia to process the manufacturing industry development following the "Czech" or "Swedish" scenarios [3] would mean the considerable increase of the manufacturing branch efficiency approximately 3 to 6 times in Latvia. The author allowed that under the chosen scenarios the modern industrial real property market of Latvia would not need any further growth.

To make the empirical study and get the practical application of the theoretical results, the author has drawn a research on a choice of a feasible location for the entrepreneurial activities in Latvia. The further substantial chapters of the Paper are the Methodology - a section explaining the methodology applied and scientific investigation of the industry location research based on the surveys and qualitative analysis listed in the scientific literature, the Empirical Study Results, including Review of Literature on the issue of the international surveys made for the industrial real estate market, Discussion Panel with a list of the issues raised to build a basis for the survey and the Model developed and introduced by the author, and Conclusions.

\section{Methodology}

A research object is an industrial real estate property market and the leading industrial multinational companies are the subject of the research. The main methods used to carry the research are the analysis of primary and secondary literary sources, applying a logical approach, comparisons, and decision-making, which indicated a theoretical background of the statistics and the issues of the market attractiveness, strategic analysis and business scope for the survey in Latvia within the Baltic Sea Region; the qualitative and quantitative data analysis to obtain a list of the required companies was made according to the multistage sampling by the typological data set method [11], [12].

The purpose of the Paper is to bring to professional critical view and assessment the preliminary results of the research.

The following objectives were set by the author: 1) to bring the main criteria and questions of the survey on the feasible location to the industrial real estate objects of the multinational companies in Latvia to a discussion panel; 2) introduce the developed model to forecast a supply of the industrial real estate market that might be used as a guideline to further analysis and comparisons of the survey's results.

The author introduced the original approach of including the European climate change issue as a basis to assign the sustainable supply of the industrial premises, applying complex of the methods like logical approach and comparison, the system and dynamic row's analyses [3].

\section{Empirical study results}

\subsection{Review of literature}

The author has studied information in the scientific works on the case of making survey for the industrial companies, analysed the results and specified useful criteria for the questionnaire.

A standard theory of the professor John H. Duning on the multinational enterprises knowledge says that success of the foreign direct investment occurs when ownership, location and internationalization (OLI triad) advantages exceed the costs of establishing and running foreign subsidiaries [13], [14].

Kronborg and Thomsen studying Denmark industry market from 1895-2005 used a matched sample methodology. The objective is to approximate a controlled experiment by matching a treatment group (foreign-owned companies) to a control group that is as similar as possible to the study group in relevant dimensions [13], [15], [16]. The sampling design is as follows: the foreign subsidiaries of manufacturing companies registered in certain years were sampled with a follow-up in the research year (2005). The data collection was made as bias free as possible by 1) identifying all foreign-owned companies in the company register, 2) choosing as control the company in the same industry category that same closest to the foreign company by assets (primary criteria) and share capital (secondary criteria). Therefore, the database consisted of 528 pairs of companies. From the personal professional background in the Baltic countries, the author agrees to Kronborg and Thomsen which cited other researchers on the idea that at the firm level the relative survival of foreign subsidiaries is likely to increase over time (with firm age) because the initial liability of foreignness is gradually overcome as a foreign subsidiary learns more about the host country environment and develops better connections to local business networks [13].

In the Heckscher-Ohlin model it is suggested that the spatial distribution of economic activity is determined by comparative advantage due to factor endowments. In turn, New Economic Geography models show the existence of a bellshaped relationship between the process of market integration and the degree of concentration of industrial activity in the territory. The analysis of the results showed that both comparative advantage and NEG-type mechanisms were determinant drivers of industrial location in Spain, although their relative strength changed over time [27], [17], [18].

Mueller and Morgan in their research on the location decision of the manufacturers in Michigan based a study on personal interviews with top executives distinguish between three kinds of location decisions: 1) the location of new firms, 2) the decision of existing firms to stay at their present location or, alternatively, to relocate, and 3) location decisions which occur in connection with expansion of facilities [16], [19]. 
The research made by Greenhut and Jackson in Florida, USA, resulted that the most important single factor which, supposedly, influenced the firm to settle business was the existence of a market for its product there and the prospects of substantial growth of that market. The second major factor in leading the firm to a location in Florida had been analysed to do with costs. The community factor includes such advantages as proximity to raw materials, an extensive local market area, superior community services and facilities as well as the existence of sufficient space for expansion, nearness of plant location to workers' homes, and similar items. Indeed, for a theory of location designed to explain why firms have located in a certain community, all of these elements are suggested to be relevant [20].

Resmini gave different identification within the neoclassical trade models. The industry location depends on the specialization of the territorial unit considered in line with comparative advantages of location's geography, factor endowments and technology [21], [22]. The researcher posed the large regions and more generally regions with good market access would become particularly attractive production locations and export bases.

Cantwell et al. argues that the main drivers for institutional entrepreneurship are now found in the increasing autonomy of multinational enterprises subsidiaries. Thus multinational enterprises agency derives from more decentralized forms of experimentation in international corporate networks, which competence-creating nodes of new initiatives can co-evolve with local institutions [23].

The results of the survey carried in Polish industrial market by Wolf Nikolaus pointed to a role for both, comparative advantage and access to markets, showing that both statistically and economically the most important factors were the endowment with skilled labor and inter-industry-linkages [24].

Michael E.Mullis in his study conducted a survey by phone and mail. The company set gained from Fortune 500 companies list [25]. The countries particularities are considered by the enterprises but one of the key issues typical for every location is a need for confidentiality in the collaboration to the community during a realization of the industrial prospect [25]. The Mullis study's results illustrated the typical issues or "real life scenarios" expressed by the industry leaders that the management solves at the every-day basis while negotiating and suffering from the rivalry in the market. Among those reasons the loss of competitive advantage of a strategic new location, impact on real estate costs and alternatives and community's and the politicians' interest are named. The impact on real estate costs and alternatives might tightly be dependent on the country's regulations system's development level and the ambitions of a landlord.

Le Bas and Sierra study is based upon a database on the European patenting activity of the largest multinational firms in France [26][27]. According to the named researchers study's results, the companies from Denmark, Germany, Norway, Sweden and USA where R\&D activities aimed at monitoring or acquiring competitive advantages which were complementary to those already possessed by the firm (strategy No. 3) [27]. Finnish companies rather followed the strategy characterized by Kuemmerle as "home-base-exploiting FDI" in R\&D (strategy No. 2) [17]. In terms of policy implications, in most cases the home country dictates the rules. The advantages built at home are at the core of strategies No. 2 and 3. This clearly shows the national system of innovation (in particular the system of academic research) should strengthen the technological advantages of local firms and enable them to succeed their location abroad.

\subsection{Discussion panel}

Summarizing the above information, for the qualitative data set the author considered the OLI triad advantages and Resmini's conclusions, marking the following limitations for the research carried in Latvia:

- ownership origin area of the enterprises is the BSR;

- the size of the companies analysed is the large and middle scale;

- certain economy branches of the working enterprises according to NACE Rev.2. classification are C, D and E categories [29].

Recalling Kronborg and Thomsen, Kuemmerle, Martinez-Galarraga, Greenhut and Jackson researchers, the author has identified the local collaboration opportunities (local authorities, scientists and business companions), local tax policy and the advantages of the local natural resources' use among the market attractiveness criteria for the list of questions predetermining a choice of the location and future development plans of the companies.

Understanding a significance of the business activity terms and plans in the subsidiary market, structured by Mueller and Morgan, the separated answer opportunities according to those criteria are provided in the developed questionnaire saving the respondents' time.

Besides, the author considered finding out a dominance of the R\&D activities in the Latvian market from the survey, giving a view on attraction of the professional local scientists to support business in a long-term.

Determining an appropriate location's criteria the author would ask about correspondence of the development plans of the administrative territory to the manufacture's requirements and expectations.

Before introducing the main results of the research the discussion on finding the suggested method (online survey) to get to the higher response rate is raised by the author in a situation when fast changing market causes the bankruptcy of the current businesses in the short time period, limitations in direct contact information, and possible low business interest to the survey or low degree of belief result the data. In all case studies analysed the dataset counted over 400 companies and a response rate of over 50 per cents is reachable by the direct contact interviewing by personal contact, telephone or rarely mail. However, the online survey method is chosen by the author as the most efficient way of controlling the answers of a large quantity of the database set in a short time period. Internationally proved practice shows that the online surveys 
normally provide low response rate at over $15 \%$, and the higher rates may be reached by reducing number of questions and sending reminders [30]-[32]. Greater anonymity rate as one of the advantages of the online questionnaire [32] is taken under consideration even in the period when cases of information leakage had appeared in Latvia. Receiving the addressed written form of the questionnaire people consider it to be safe and take the opportunity of completing the survey when have time that cannot be allocated during the phone calls or direct interviews.

To increase interest the author outlined and followed four main tasks for the survey: 1) to determine the influence of a level and conditions of the market development when company enters the Latvian market and continues its business in Latvia; 2) to define threats in a territory acquisition; 3) to analyze if the current locations, including the premise conditions, match the requirements of the enterprises; 4) give a summarize the R\&D strategy when working in Latvia; as well as offered the respondents an opportunity to get the summary.

\subsection{The model}

There is an evident misbalance in the Latvian real estate market and inland industry locations' characteristics often do not meet requirements of the operating companies [9], and recent economic crisis influence. Therefore, low market capacities, limitations of the locations' physical and strategic development characteristics, protective tax policy and recent brain drain create threats for attracting foreign businesses to Latvia, and the author considered „competition effect”, „local market particularities” and ,investment environment”, „locational strategy” and „multinational cooperation” [27], [33], [34] in a questionnaire.

When looking at the business allocating and local market development plans issue the author categorized it in three types of collaboration: 1) industry and agriculture; 2) trade and services; 3) construction as a support and interaction branch. The Baltic Sea Region namely includes the following areas: EU member states Denmark, Estonia, Finland, Latvia, Lithuania, Poland, Sweden and northern parts of Germany, as well as the neighboring countries of Norway, north-west regions of Russia and Belarus.

Recently the Latvian modern industrial real property stock accounted 0,45 million square meters (24 times less than in Sweden and 8 times less than in Czech), that is 2,900 euro of the industrial capacities per 1 sq.m of the modern industrial premises (that is 3 times higher than in Sweden and 7 times less than in Czech) [1]. Here, the author concluded, that Latvia might process the manufacturing industry development following the Czech or Swedish scenarios (referring to Table 1), which mean a considerable increase of the manufacturing branch efficiency approximately 3 to 6 times in Latvia, the author allowed that the modern industrial real property market does not need any further growth under the chosen scenarios [3].

Table 1. Collation of the 2035 forecast and 2009 statistics. The Latvian case results to times [3]

\begin{tabular}{llll}
\hline Ratio $\backslash$ Country scenario & 1 & 2 & 3 \\
\hline Agriculture, gross value added & 0.43 & 0.78 & 0.60 \\
Manufacturing, gross value added & 2.36 & 1.00 & 1.67 \\
Manufacturing percent from GDP in 2020 & 0.54 & 0.38 & 0.46 \\
Modern industrial real estate property stock & 0.41 & 1.71 & 0.55 \\
$\begin{array}{l}\text { Manufacturing gross value added per 1 sq.m of } \\
\text { modern industrial property }\end{array}$ & 5.75 & 0.32 & 3.04 \\
\hline
\end{tabular}

The calculations are made from the developed algorithm model of the forecasting a supply of the spatial economic objects on the basis of the climate change analysis detecting the comparable focus countries territories for the further industrial property stock assessment. In a context of the research to evidentiate a connection of the industrial real estate business market to a system of the entrepreneurial activities influenced by miscellaneous factors, a commercial real estate object (industrial real estate object in a context) is defined as the spatial economic object in the model illustrated in Figure 1.

A discussion for the academic environment is forwarded by the author to the analytics may be adjusted with the wind speed, relative humidity, surface pressure, precipitation, soil moisture, sea ice temperature and other measures to complete the data set.

The author connected two general blocks: regional economic planning within a certain region and real estate business as a support function to industrial market development. Regional economic planning is often directed towards stimulating commercial and industrial environment of a region. Assessing the regional spatial structure and planning, the main goal of it is to coordinate and ensure with the guidelines in land use, infrastructure development, transport, services and economy development and other sectors' and interests' maintenance [26], [1]. Here, Latvia could cumulate all its force on servicing these big neighbors, but it does not. For this purpose it must have strong professional specialists and well developed infrastructure. Otherwise, the author suggests paying a very strong attention to the quality of the existing real estate objects and surrounding infrastructure supporting business in a middle and long-term. The author expects the respondents of the survey would see the potential and perspectives of keeping business on-going and increasing the capacities in Latvia within a scale of the Baltic Sea Region. 


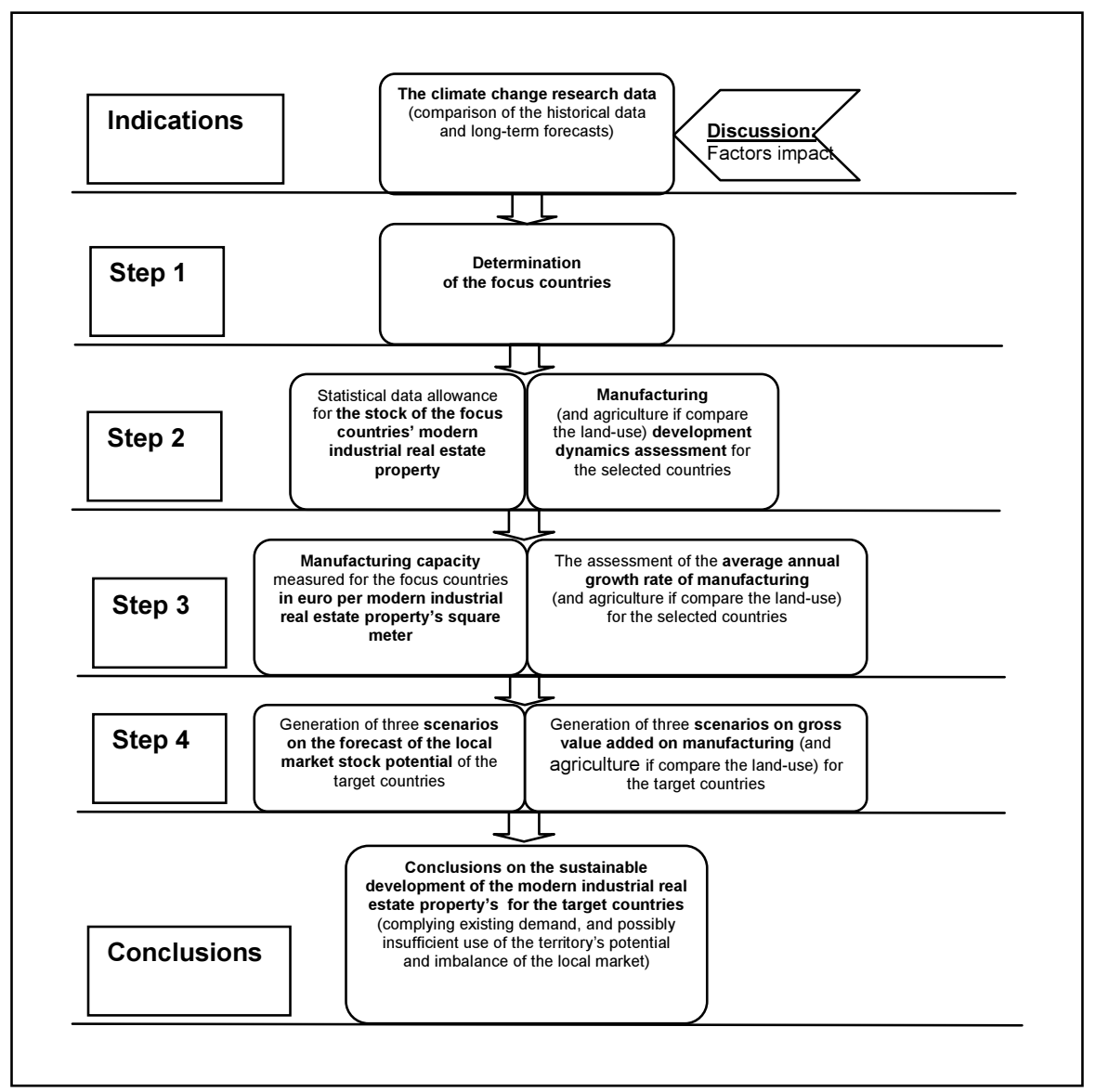

Fig. 1. The algorithm model of the forecasting a supply of the spatial economic objects

The author has analyzed several problems in assessing the consequences of the headquarters' decisions to enter the foreign markets. Formulating the most feasible location criteria, it would be logical to agree to Cantwell et al., but accepting Latvia as developing economy market, the author assumed, it might be influenced by a choice of headquarter, collaboration perspectives with the local authorities, the development plans of the administrative territory or location correspondence to the manufacture's requirements. The author's expectations on the answers to the remarkable questions given in Appendix A are the following:

Question 1. As the major database set is of the leading companies, the major activity expected within the last one or two decades.

Question 3. The administration office probably will be located in the same territory with local industrial premises.

Questions 2 and 11. The author assumed that "Latvia's advantageous geopolitical location" together with and "proximity to the materials" might be most highly valued from the rest especially for the business start period. The lowest rates could get the answers "Attractive tax policy" and "The company has full manufacturing process organized in Latvia, including its realization in local market" in case of subsidiaries. As an optimum for starting business the most positive answer could be for the companies' careful and tight collaboration with the local communities, and low support from the local side and local tax legislation, poor percentage of the local forces use in the corporation's R\&D activities, certain collaboration with local business units with a strong orientation on the further market outlets outside Latvia (wood manufacture, food products lines and others).

Questions 8. According to the stagnation in market the most probably the companies do not plan any changes for the nearest five years.

Question 9. The most "No" answers could get the characteristics of the premises due to certain limitations of being in industrial parks or taking the old factories building, the land plot due to the land plot physical limitations or connection to the road and distribution channels, and transport infrastructure due to still low quality of the roads connections in Latvia and possibly far proximity to the supply markets or materials.

Question 14. Merger and acquisition became rather popular in the last decade due to local companies assets limitations and often bankruptcy.

The most probably, the survey results would show that the middle scale multinational industrial business companies worked under condition of a short-term planning in Latvia, and only the industry leaders implemented the strategic planning. The corporate business could have built-to-suit or rent premises in the industrial parks, the others who got the old factories' permanent facilities would face a need of the modernization investment in a long-term perspective. 


\section{Conclusions}

The Paper is a message to professional critical view and assessment on the developed model and the questionnaire. The author highlights the following issues: the role of the market development stage and conditions; the main obstacles in the location choosing and territory's planning and management, the companies' strategic plans. Four tasks are set for the survey: 1) to determine the influence of a level and conditions of the market development when company enters the Latvian market and continues its business in Latvia; 2) to define threats in a territory acquisition; 3) to analyze if the current locations, including the premise conditions, match the requirements of the enterprises; 4) give a summarize the R\&D strategy when working in Latvia. The hypothesis of the research, namely, Latvia does not use its advantageous location effectively, supported by the previous researches' results and marked to be proved by the survey according to the defined questions. From the pointed expectations on the answers the one may resume that the hypothesis is expected to be one of the major conclusions from the planned survey that would show that the majority of the existing location and premises characteristics could not perfectly require a satisfactory level of the current industrial business market leaders.

The author's pessimistic expectation was on the response rate to the online survey due to limitations in direct contact information, fast changing market causing the bankruptcy of the current businesses in the short time period and rare business interest to the questionnaires. However, the author assumed the online survey might be the most efficient way of controlling the answers of a large quantity of the database set in a limited time period. By searching for the direct contacts through personal contacts database and adding it using the online business networks or database of the marketing companies, as well as thinking over the planned results and introducing the main questions at the start of the interview to get the interest and must to have reasons to persuade the managers to answer the questionnaire, the author believed to rise the responses up to higher rate.

In generally, the author expects that a climate change issue so far is not strictly regulated in Latvia and industrial business units do not measure it as the alternative or threat to further business development. Here, the introduced algorithm model of the forecasting a supply of the spatial economic objects would show a new way of planning the industrial business scales analyzing the existing European practices and capacities.

\section{References}

[1] Staube, T. 2013. Issues of spatial economic allocation of the entrepreneurial activities in Latvia. Summary of PhD Thesis. - Riga: RTU Publishing House.- 63 p. ISBN 978-9934-10-484-8

[2] Āboliņa, K.; Andrušaitis, A.; Blumberga, D.; Briede, A.; Bruņiniece, I.; Grišule, G.; Kḷaviņš, M. 2008. Klimata mainība un globālā sasilšana. - Riga: LU akadēmiskais apgāds. 174 p.

[3] Staube, T.; Geipele, I. 2012. Latvijas industriālo telpu ilgtspējīgā piedāvājuma scenāriju analīze klimata pārmaiṇu ietekmē (Analysis of scenarios on the industrial premises' sustainable supply in Latvia under the influence of the climate change), in Climate change and adaption to it: Latvia. M.Klavins and A.Briede Eds. Riga: University of Latvia Press, 170-186.

[4] Staube, T.; Geipele, I. 2013. Decisions on industry location and market capacities in Latvia, Advanced Materials Research 664: $1141-1145$.

[5] Staube, T.; Geipele, I. 2012. Industry location assessment for multinational enterprises in Latvia, in Proc. of the 2nd World Sustain. Forum, 2012. Sciforum Electronic Conferences Series, 2012. ISBN 3-906980-28-6

[6] Staube, T.; Geipele, I. 2013. The concept of the Latvian industrial property market development model in a context of the strategic planning [online], in European Real Estate Society 20th Annual Conference (ERES 2013), Vienna, Austria, July 3-6, 2013. ERES Digital Library [accessed 23 January 2014]. Available from Internet: http://library.eres.org/eres2013/paperupload/156.pdf

[7] Staube, T.; Geipele, I. 2011. The latest trends in the spatial planning modeling of the Baltic Sea Region determine a territory's potential, in Proc. Int. Conf. on Social Sciences and Society (ICSS 2011), Shanghai, China, 2011. Newark: Information Engineering Research Institute , $403-409$.

[8] Staube, T.; Geipele, I. 2012. The macroregion approach and territorial cohesion of the Baltic region, International Journal of Systems Applications, Engineering and Development 6(1): 70-78.

[9] Staube, T.; Geipele, I. 2012. Does Latvia use its advantageous location?, in Proc. of the 25th European Conference on Operational Research EURO2012, Vilnius, Lithuania, 2012. Vilnius: EURO, 17.

[10] Staube, T.; Geipele, I. 2012. Economically Advantageous Location Assessment for the Industrial Business in Latvia, in Proc. of Riga Technical University 53rd International Scientific Conference. Dedicated to the 150th Anniversary and The 1st Congress of World Engineers and Riga Polytechnical Institute / RTU Alumni, Riga, Latvia, 2012. Digest. Riga: Riga Technical University, CD version, 756. ISBN 978-9934-10360-5

[11] Lasmanis, A. 2002. Datu ieguves, apstrādes un analīzes metodes pedagogijas un psihologijas pētījumos. 1.grāmata. Riga : Izglītības soḷi. 236 p.

[12] Mārtinsone, K. 2011. Ievads pētniecībā: stratēgijas, dizaini, metodes. Riga: Raka. 284 p.

[13] Kronborg, D.; Thomsen, S. 2009. Foreign ownership and long-term survival, Strategic Management Journal 30(2): $207-219$. http://dx.doi.org/10.1002/smj. 732

[14] Dunning, J. H. 1981. International Production and the Multinational Enterprise. London, UK: Allen \& Unwin. 440 p.

[15] Breslow, N. E. 1996. Statistics in epidemiology: the casecontrol study, Journal of the American Statistical Association 91(433): 14-28. http://dx.doi.org/10.1080/01621459.1996.10476660

[16] Mezias, J. M. 2002. Identifying liabilities of foreignness and strategies to minimize their effects: the case of labor lawsuit judgments in the United States, Strategic Management Journal 23(3): 229-244. http://dx.doi.org/10.1002/smj.220

[17] Kuemmerle, W. 1999. Foreign investment in industrial research in the pharmaceutical and electronics industries-results from a survey of multinational firms, Research Policy 28(2/3): 179-193. http://dx.doi.org/10.1016/S0048-7333(98)00110-3

[18] Martinez-Galarraga, J. 2012. The determinants of industrial location in Spain, 1856-1929, Explorations In Economic History 49(2): 255275. http://dx.doi.org/10.1016/j.eeh.2011.05.012

[19] Mueller, E.; Morgan, J. N. 1962. Location decisions of manufacturers, American Economic Review 52(2): $204-217$.

[20] Greenhut, M. L.; Jackson, F. H. 1960. The Community and Industrial Development: A Case Illustration of Location Problems, Southwestern Social Science Quarterly 41(3): 320-334. 
[21] Resmini, L. 2009. Cities in Globalization: Practices, Policies and Theories, edited by Peter J. Taylor, Ben Derudder, Pieter Saey, and Frank Witlox, Journal of Regional Science 49(1): 228-230.

[22] Resmini, L. 2007. Regional Patterns of Industry Location in Transition Countries: Does Economic Integration with the European Union Matter?, Regional Studies 41(6): 747-764. http://dx.doi.org/10.1080/00343400701281741

[23] Cantwell, J.; Dunning, J. H.; Lundan, S. M. 2010. An evolutionary approach to understanding international business activity: The co-evolution of MNEs and the institutional environment, Journal of International Business Studies 41(4): 567-586. http://dx.doi.org/10.1057/jibs.2009.95

[24] Wolf, N. 2007. Endowments vs. market potential: What explains the relocation of industry after the Polish reunification in 1918?, Explorations in Economic History 44(1): 22-42. http://dx.doi.org/10.1016/j.eeh.2005.08.003

[25] Mullis, M. E. 1994. Understanding and responding to prospect confidentiality, Economic Development Review 12 (3): 91.

[26] Auzins, A. 2008. Zemes pārvaldības pamati. Riga: RTU Publishing House. 107 p.

[27] Le Bas, Ch.; Sierra, Ch. 2002. Location versus home country advantages' in R\&D activities: some further results on multinationals' locational strategies, Research Policy 31(4): 589-609. http://dx.doi.org/10.1016/S0048-7333(01)00128-7

[28] Dunning, J.; Narula, R. 1995. The R\&D activities of foreign firms in the United States, International Studies of Management and Organization 5 $(1 / 2): 39-74$

[29] NACE classification coding. European Commission. [online] [accessed August 14, 2010]. Available from Internet: $\mathrm{http}$ ///ec.europa.eu/competition/mergers/cases/index/nace_all.html.

[30] Kristapsone, S. 2008. Zinātniskā pētniecība studiju procesā. Riga: SIA “Biznesa augstskola Turība". 352p.

[31] Cook, C.; Health, F.; Thompson, R. L. 2000. A meta analysis of response rates in web or internet based surveys, Educational and Psychological Measurement 60(6): 821-836. http://dx.doi.org/10.1177/00131640021970934

[32] Kumar, R. 2005. Research methodology. 2nd edition. A step-by-step guide for beginners. London: SAGE Publicaton Ltd. 332 p.

[33] Staube, T.; Geipele, I. 2011. Valuation of the Swedish Direct Investment Territorial Allocation in the Context of Latvian Commercial Property Development, in Proc. of the 8th International Conf. On Environmental Engineering: Selected papers, vol.3. Ed. by D.Cygas and K.D. Froehner. Vilnius, Lithuania, May 19-20, 2011. Vilnius: Technika, 993-1000.

[34] Yeaple, S. R. 2003. The complex integration strategies of multinationals and cross country dependencies in the structure of foreign direct investment, Journal of International Economics 60(2): 293-314. http://dx.doi.org/10.1016/S0022-1996(02)00051-X

\section{Acknowledgements}

The author wishes to express her gratitude to the Institute of the Civil Engineering and Real Estate Economics at RTU for financial support in publication and presentation of the research results.

\section{Appendix A. List of the main specialty questions for the survey}

\begin{tabular}{|c|c|}
\hline Question No. & Question definition (excluding answering option of "other reason") \\
\hline A. & Market attractiveness and location assessment \\
\hline 1. & When did the Company enter the Latvian market? \\
\hline 2. & $\begin{array}{l}\text { The Latvian market attractiveness criteria WHEN the Company ENTERED THE MARKET } \\
\text { - Advantageous strategic geographic location } \\
\text { - Attractive tax policy } \\
\text { - Low level of competition } \\
\text { - Low price level of the raw materials in Latvia used as the main products in the Company's business } \\
\text { - } \text { activities } \\
\text { - } \text { Beneficial credit terms and conditions for the industrial business } \\
\text { - The advance to use the local natural resources for the manufacture } \\
\text { - } \text { Aatvia has appropriate ecological conditions } \\
\text { - Low labor costs } \\
\text { - Well-developed transport infrastructure in the country } \\
\text { - The Company has full production process and product realization activities for the local market } \\
\text { organized in Latvia }\end{array}$ \\
\hline 3. & Does the Company rent the industry premises in industrial park in Latvia? \\
\hline 4. & How many industry locations does the Company have in Latvia? \\
\hline 5. & $\begin{array}{l}\text { What is the total size of the industry locations and premises occupied by the Company in Latvia? } \\
\text { - } \quad \text { total land plot area (including the area under the buildings), ha } \\
\text { - gross floor space of the occupied industrial premises, square meters }\end{array}$ \\
\hline 6. & $\begin{array}{l}\text { What factors determined a permanent solution to choose the existing location/locations? } \\
\text { - Proximity to raw materials } \\
\text { - } \quad \text { Proximity to the local partners } \\
\text { - } \quad \text { Proximity to the customers (market outlet) } \\
\text { - } \text { economic and transport infrastructure and utilities in a neighborhood) } \\
\text { - } \quad \text { The best fit to our requirements to the industrial premises } \\
\text { - It was the only decision of the Headquarters }\end{array}$ \\
\hline
\end{tabular}


Continued Appendix A

\begin{tabular}{|c|c|}
\hline Question No. & Question definition (excluding answering option of "other reason") \\
\hline 7. & Has the Company changed the location/ locations in Latvia since the beginning of the business here? \\
\hline 8. & $\begin{array}{l}\text { The Company's plans for the next five (5) years in Latvia } \\
\text { - Expansion of business } \\
\text { - } \quad \text { Production cut } \\
\text { - Closing the business in Latvia and move the assets to another country }\end{array}$ \\
\hline 9. & $\begin{array}{l}\text { Does the Company plan to change any of its existing location within the next five (5) years? If yes (also if the } \\
\text { Company is moving the assets to another country), please name all the factors determined that decision } \\
\text { - Insufficient physical characteristics of the existing land plot } \\
\text { - Bad conditions of the existing industrial premises } \\
\text { - Low capacity of the utility system } \\
\text { - Insufficient transport infrastructure and road communications in the neighborhood } \\
\text { - High level of the rent rate }\end{array}$ \\
\hline 10. & $\begin{array}{l}\text { What is the total planned size of the industry locations and premises occupied by the Company in the next five } \\
\text { (5) years in Latvia? }\end{array}$ \\
\hline 11. & $\begin{array}{l}\text { Please give the Company's assessment on the CURRENT Latvian market attractiveness criteria. This question is } \\
\text { different from the question No.2. } \\
\text { Answer options similar to the named in question No.2. }\end{array}$ \\
\hline B. & The corporative identity of the Company \\
\hline 12. & The Company's status in Latvia: Headquarter or Subsidiary \\
\hline 13. & How many employees does the Company have in Latvia? \\
\hline 14. & Has the Company experienced the merger and acquisition process since entering the Latvian market? \\
\hline 15. & The Company headquarters' country location in BSR \\
\hline 16. & Does the Concern have the subsidiaries outside Latvia? \\
\hline 17. & Please mark all markets of the entire Latvian branch business activities in 2012 (choice from BSR region) \\
\hline 18. & Please mark all markets of the entire Concern's business activities in 2012 (choice from BSR region) \\
\hline C. & R\&D strategy \\
\hline 19. & $\begin{array}{l}\text { Has the Company engaged the local researchers for the Corporate Research and Development since entering the } \\
\text { Latvian market? }\end{array}$ \\
\hline 20. & $\begin{array}{l}\text { Does the Company plan Research and Development for the next } 5 \text { years? } \\
\text { - The Company plans to attract the local scientists } \\
\text { - The Company plans to attract foreign scientists } \\
\text { - The Company does not plan Research and Development for the next } 5 \text { years }\end{array}$ \\
\hline
\end{tabular}

